\title{
Is screening for bacteriuria in pregnancy worth while?
}

\author{
M CAMPBELL-BROWN， I R MCFADYEN， D V SEAL， M L STEPHENSON
}

\begin{abstract}
A total of $\mathbf{4 4 7 0}$ pregnant women were screened for bacteriuria by the dipslide method and significant growth found in $226(5 \cdot 1 \%)$. In 198 cases the urine was re-examined, in 119 by using suprapubic aspiration or catheterisation $(62(52 \%)$ samples contained bacteria) and in 79 by using midstream urine samples (26 (33\%) samples contained $>10^{8}$ colony forming units/1), showing the maximum prevalence of confirmed bacteriuria to be $2 \cdot 6 \%$. Overt urinary tract infection developed later in four of 80 patients with proved bacteriuria who had been given antibiotics, in one of eight untreated patients with bacteriuria, in one of 110 patients with unconfirmed bacteriuria, and in one of 226 non-bacteriuric controls. A history of urinary tract infection was given by $18 \%$ of controls and $42 \%$ of women with confirmed bacteriuria.

Screening for bacteriuria and treatment with antibiotics to prevent later overt infection is expensive. Whether it is worth while and cost effective depends largely on the prevalence of bacteriuria in the local population and the proportion who develop overt infection. The screening and treatment programme reported here appeared to prevent only six cases of overt infection.
\end{abstract}

\section{Introduction}

Asymptomatic bacteriuria during pregnancy has been known for years to be associated with an increased risk of overt urinary tract infection but the magnitude of this risk and the effectiveness of antibiotics in reducing it are still a matter of controversy 25 years later. ${ }^{\prime}$ It is generally accepted, however, that $11-40 \%$ of women

\footnotetext{
Section of Perinatal Medicine and Child Health, Clinical Research Centre, Northwick Park Hospital, Harrow, Middlesex HA1 3UJ

M CAMPBELL-BROWN, MB, CHB, clinical assistant

I R MCFADYEN, FRCOG, consultant obstetrician and gynaecologist

Division of Communicable Diseases, Clinical Research Centre, Northwick Park Hospital, Harrow, Middlesex HA1 3UJ

D V SEAL, MD, consultant microbiologist

M L STEPHENSON, MSC, research technician

Correspondence to: $\mathrm{Mr}$ McFadyen.
}

who have bacteriuria in early pregnancy and $1-3 \%$ of those who do not will develop overt infection before delivery. ${ }^{1.5}$

The prevalence of bacteriuria is not increased by pregnancy above the $2-10 \%$ found in women of reproductive age. ${ }^{1}$ This difference partly depends on the method of screening and definition of bacteriuria; for example, a single midstream specimen of urine may yield a $40 \%$ false positive rate, largely owing to urethral or vulval contamination. ${ }^{67}$ The socioeconomic state of a population is also relevant, bacteriuria being more common in women of low social class. ${ }^{89}$

Other factors affect the evaluation of screening and treatment programmes. Not all bacteriuria is present early in pregnancy; $0.5-$ $1.0 \%$ of women develop it later and are not therefore offered prophylactic antibiotics. ${ }^{23}$ Other women decline the offer of further investigation and treatment, often passively by failing to attend clinics. Treatment is not always successful. A single course will clear $50-90 \%$ of infections but further courses may be required before the bacteriuria clears, and in a few cases treatment fails completely. ${ }^{237}$ The choice of antibiotics and the duration of treatment also influence the success rate. There is evidence that a history of overt infection before pregnancy increases the risk of overt infection during pregnancy in mothers with bacteriuria. In one study mothers with bacteriuria and a previous history were four times more likely to develop overt infection than those without such a history and 10 times more likely than those without either bacteriuria at booking or a previous history.

The effectiveness of any programme designed to prevent overt infection will be influenced by the criteria used to define the condition. "Several studies have shown that only $30-50 \%$ of women with clinical symptoms have infected urine. ${ }^{3111}$ Even when the clinical criteria have been clearly defined outcome has varied widely. In one controlled trial of prophylactic treatment $96 \%$ of overt infections in bacteriuric pregnant women were apparently prevented, but the figure usually quoted is $60-70 \% .^{1}$ Nevertheless, whatever proportion of overt infection is prevented in bacteriuric women most cases occur among the $\mathbf{9 0 - 9 8 \%}$ of women screened and found not to have bacteriuria. They are not offered antibiotics because of their comparatively low risk of developing overt infection.

As antenatal screening for bacteriuria and its subsequent treatment is expensive, we reviewed the incidence of overt infection in a population in whom the number with a previous history of urinary tract infection was known, bacteriuria was confirmed by a second test, and prophylactic antibiotics were given to determine 
how effective this policy was in preventing overt infection during pregnancy. The study was approved by the Northwick Park Hospital's ethical committee.
$30 \mu \mathrm{g}$, Augmentin $30 \mu \mathrm{g}$ (amoxycillin $20 \mu \mathrm{g}+$ clavulanic acid $10 \mu \mathrm{g}$ ), sulphamethoxazole $100 \mu \mathrm{g}$, trimethoprim $1 \cdot 25 \mu \mathrm{g}$, and nitrofurantoin $200 \mu \mathrm{g}$.

\section{Results}

Apparent bacteriuria on dipslide screening was found in $226(5 \cdot 1 \%)$ of the 4470 patients studied. Confirmatory tests were possible in 198 patients, 106 by suprapubic aspiration, 13 by catheterisation, and 79 by a second midstream urine specimen. Bacteriuria was present in $62(52 \%)$ of those examined by suprapubic aspiration or catheterisation and in $26(33 \%)$ of those with midstream urine specimens, a significantly smaller proportion than with the suprapubic and catheter samples $(p<0.05)$. The remaining 28 patients failed to return for a second urine test. The prevalence of confirmed bacteriuria in this population was therefore between $2 \cdot 0 \%$ and $2 \cdot 6 \%$ (figure).

A previous history of urinary tract infection was given by $94(42 \%)$ of the 226 patients with apparent bacteriuria, a significantly greater proportion than the $41(18 \%)$ among the 226 controls $(p<0.001)$. There was no significant difference between those with confirmed bacteriuria (41 out of 88 ) and those with positive dipslides only (45 out of 110$)$.

Eighty of the 88 patients with confirmed bacteriuria accepted treatment. The first course of antibiotics was initially successful in 69 . In the double blind trial, where follow up was complete, Miraxid was given to 24 patients. Treatment was successful in 14, failed in six, and in four the bacteriuria recurred after clearing initially. Cephalexin was given to 23 patients and was successful in 17, failed in one, and bacteriuria recurred in five. Neither treatment was significantly more effective than the other in clearing the bacteriuria. It was not possible to compare treatments in the remaining 33 patients because of different antibiotics and duration of use.

Overt infection was diagnosed later in pregnancy in seven patients, three of whom had had a history of urinary infection before this pregnancy. Of these seven cases, one occurred in the control group, one was in the group with unconfirmed bacteriuria, and five were in patients who had confirmed bacteriuria, of whom four had been given antibiotics and one had not. There was no significant difference in the incidence of overt infection among any of these four groups of mothers (figure), but the number of cases in each was small. Among the 226 mothers with apparent bacteriuria the incidence of overt infection was $2 \cdot 7 \%$, and for the control group $0 \cdot 4 \%$.

Table I lists the organisms isolated from the urine samples obtained by suprapubic aspiration or catheterisation. Escherichia coli predominated, and in one case the infection was due to the anaerobe Bacteroides corrodens. care. Overt infection was defined as severe renal angle or abdominal pain together with fever and at least one urine sample containing significant numbers of bacteria. Two patients were included who had similar severe symptoms but no growth in a midstream urine specimen obtained before treatment was given. ${ }^{12}$

To assess the effectiveness of prophylactic antibiotics in preventing overt infection we compared our data with those published from Aberdeen, where antibiotics were given only for overt infections. ${ }^{5}$ In a logistic regression the approximate relative risk (or odds ratio) of overt infection in Aberdeen was compared with that in our population. Allowance was made for a past history of overt infection and for the presence or absence of bacteriuria on screening a single midstream urine specimen. For all comparisons between groups of patients the $\chi^{2}$ test was used.

\section{LABORATORY TECHNIQUE}

Dipslides (Oxoid Ltd) were placed vertically in fresh midstream urine specimens produced in the antenatal clinic, removed, replaced in containers, and incubated at $37^{\circ} \mathrm{C}$ for about 18 hours. The result was considered significant when colony counts were estimated as $>10^{8} / 1$. A $0.005 \mathrm{ml}$ drop of fresh urine collected by suprapubic aspiration or catheterisation was cultured on each of blood, Lactobacillus (modified Rogosa ${ }^{13}$ ), and cystinelactose-electrolyte deficient (Oxoid) agars and incubated at $37^{\circ} \mathrm{C}$ in $4 \%$ carbon dioxide for 24-48 hours. In addition, 0.005 ml urine was cultured on each of blood, Veillonella (modified MacFarlane ${ }^{14}$ ) and Bacteroides ${ }^{15}$ agars, and brain-heart infusion agar containing cysteine and blood and incubated anaerobically at $37^{\circ} \mathrm{C}$ for up to seven days. When colonies were counted suprapubic aspirates were considered positive if any organisms were found and catheter specimens of urine considered positive if $>10^{7}$ colony forming units (CFU)/l were present. The midstream samples of urine were similarly cultured on blood and cystine-lactose-electrolyte deficient agars and incubated in $4 \%$ carbon dioxide at $37^{\circ} \mathrm{C}$ for up to 48 hours. These specimens were considered to confirm infection if there were $>10^{8} \mathrm{CFU} / \mathrm{l}$.

The organisms isolated were identified by standard methods and sensitivity testing carried out with the following discs: Miraxid (ampicillin $10 \mu \mathrm{g}+$ mecillinam $10 \mu \mathrm{g}$ ), ampicillin $25 \mu \mathrm{g}$, mecillinam $25 \mu \mathrm{g}$, cephalexin
TABLE I-Organisms isolated by suprapubic aspiration and catheterisation of 62 women at second attendance at antenatal clinic

\begin{tabular}{lc}
\hline & No(\%) of isolations \\
\hline Escherichia coli & $47(75 \cdot 8)$ \\
Klebsiella pneumoniae & $3(4 \cdot 8)$ \\
Staphylococcus epidermidis & $3(4 \cdot 8)$ \\
Citrobacter diversus leviniae & $2(3 \cdot 2)$ \\
Group B streptococci & $2(3 \cdot 2)$ \\
Enterobacter cloacae & $1(1 \cdot 6)$ \\
Proteus mirabilis & $1(1 \cdot 6)$ \\
Streptococcus faecalis & $1(1 \cdot 6)$ \\
Bacteroides corrodens & $1(1 \cdot 6)$ \\
Candida albicans & $1(1 \cdot 6)$ \\
\hline Total & \\
\hline
\end{tabular}

Overall $88 \%$ of isolates were sensitive to nitrofurantoin, Augmentin, and Miraxid; $73 \%$ were sensitive to cephalexin, $69 \%$ to mecillinam, $61 \%$ to ampicillin, $44 \%$ to trimethoprim, and $26 \%$ to sulphamethoxazole. This high level of resistance to trimethoprim and sulphamethoxazole is common to all types of urinary infection in this part of London.

On comparing results at Northwick Park Hospital with the published data from Aberdeen (table II) it was evident that the two populations differed both in the prevalence of bacteriuria on screening (11.9\% in Aberdeen compared with $5 \cdot 1 \%$ at Northwick Park) and in the proportion of patients with bacteriuria who gave a previous history of urinary tract infection (24\% in Aberdeen and $42 \%$ at Northwick Park). Table III shows the relative risk in the two populations of acquiring an overt infection taking into account bacteriuria found on screening and previous history of urinary tract infection. The risk was greater in Aberdeen in all combinations of risk 


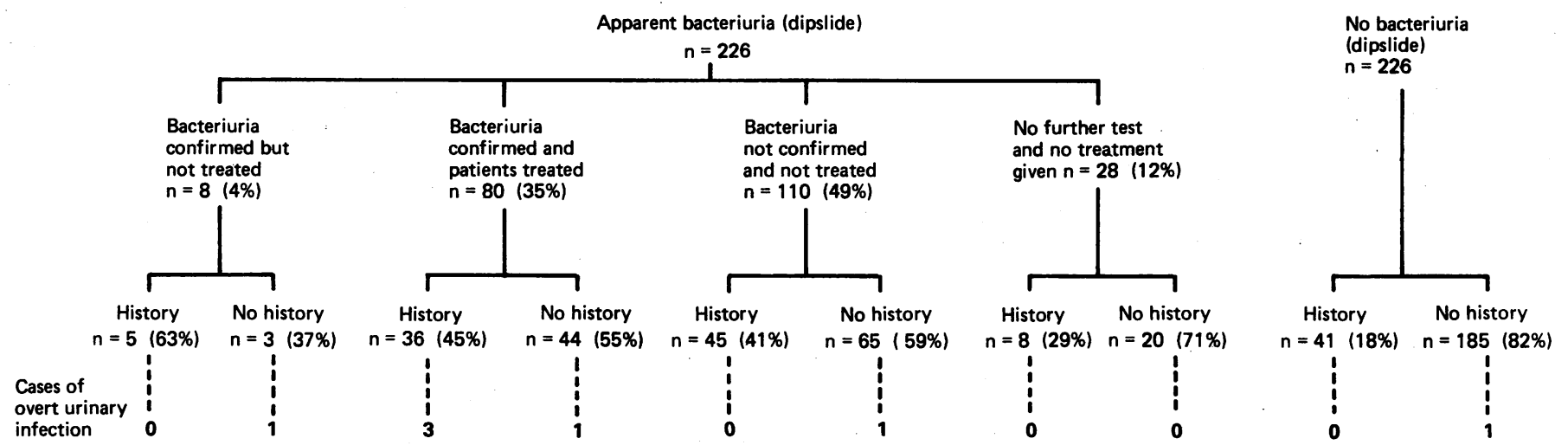

Bacteriuria, past history of overt urinary tract infection, and subsequent development of overt urinary tract infection in pregnancy in population generally treated for asymptomatic antenatal bacteriuria.

TABLE II-Comparison of pregnant populations of Northwick Park Hospital and Aberdeen screened for bacteriuria (antibiotic treatment given at Northwick Park Hospital only)

\begin{tabular}{lcc}
\hline & $\begin{array}{c}\text { Northwick Park } \\
\text { Hospital }\end{array}$ & Aberdeen \\
\hline Population surveyed & 4470 & 1787 \\
Prevalence of bacteriuria on screening (\%) & $5 \cdot 1$ & $11 \cdot 9$ \\
Previous history of urinary tract infection (\%): & $42 \cdot 0$ & $24 \cdot 0$ \\
$\quad$ Bacteriuric patients & $18 \cdot 0$ & $20 \cdot 0$ \\
$\quad$ Non-bacteriuric patients & & \\
Overt urinary tract infection later in & & $11 \cdot 8$ \\
index pregnancy (\%): & $2 \cdot 7$ & $3 \cdot 2$ \\
$\quad$ Bacteriuric patients & $0 \cdot 4$ & \\
\hline
\end{tabular}

TABLE III-Urinary tract infection during pregnancy in two antenatal populations screened for asymptomatic bacteriuria and past history of urinary tract infection (antibiotic treatment of asymptomatic bacteriuria offered to population at Northwick Park Hospital only)

\begin{tabular}{|c|c|c|c|c|}
\hline $\begin{array}{l}\text { Urinary tract } \\
\text { characteristics }\end{array}$ & Infection or not & $\begin{array}{c}\text { Northwick Park } \\
\text { Hospital }\end{array}$ & Aberdeen & $\begin{array}{l}\text { Approximate relative } \\
\text { risk (odds ratio) in } \\
\text { Aberdeen }{ }^{\star}\end{array}$ \\
\hline $\begin{array}{l}\text { No past history and } \\
\text { no bacteriuria }\end{array}$ & $\begin{array}{l}\text { Infection } \\
\text { No infection }\end{array}$ & $\begin{array}{r}1 \\
184\end{array}$ & $\begin{array}{r}36 \\
1228\end{array}$ & $5 \cdot 4$ \\
\hline $\begin{array}{l}\text { Past history but } \\
\text { no bacteriuria }\end{array}$ & $\left\{\begin{array}{l}\text { Infection } \\
\text { No'infection }\end{array}\right.$ & $\begin{array}{r}0 \\
41\end{array}$ & $\left.\begin{array}{r}15 \\
296\end{array}\right\}$ & $\infty$ \\
\hline $\begin{array}{l}\text { No past history } \\
\text { but bacteriuria }\end{array}$ & $\begin{array}{l}\text { Infection } \\
\text { No infection }\end{array}$ & $\begin{array}{r}3 \\
129\end{array}$ & $\left.\begin{array}{r}11 \\
151\end{array}\right\}$ & $3 \cdot 1$ \\
\hline $\begin{array}{l}\text { Past history } \\
\text { and bacteriuria }\end{array}$ & $\begin{array}{l}\text { Infection } \\
\text { No infection }\end{array}$ & $\begin{array}{r}3 \\
91\end{array}$ & $\left.\begin{array}{l}14 \\
36\end{array}\right\}$ & 11.9 \\
\hline
\end{tabular}

$\star$ Risk at Northwick Park taken as 1 .

factors, even when there was no bacteriuria and therefore no treatment given in either population. The pooled estimate of approximate relative risk in Aberdeen with that at Northwick Park taken as 1 was $4.0(p<0.001)(95 \%$ confidence interval $1 \cdot 7$ to $9 \cdot 6$ ).

\section{Discussion}

The prevalence of bacteriuria in this population $(5 \cdot 1 \%$ found by dipslide screening, $2 \cdot 0-2 \cdot 6 \%$ after a second, confirmatory test) lay in the reported range of $2-10 \% .^{1-35712}$ Bacteriuria was confirmed in $52 \%$ of patients in the suprapubic aspiration or catheterisation group, which is similar to the $59 \%$ found in an earlier suprapubic aspiration study in Harrow. ${ }^{7}$ A Lambeth population screened by suprapubic aspiration had a prevalence of bacteriuria of $6.6 \%$, which was more likely to be due to differences in social class than a secular trend. ${ }^{16}$ Patients whose apparent bacteriuria was confirmed by suprapubic aspiration had a significantly higher prevalence than the $33 \%$ confirmed with midstream urine samples, a difference which probably reflects the greater sensitivity of methods using bladder urine. ${ }^{17} 18$

A previous history of overt infection was given by $18 \%$ of the control group at Northwick Park, and if we extend this to all patients without bacteriuria the overall incidence for the whole pregnant population would be $19 \%$, which is similar to the $20 \%$ found in the Aberdeen study (table II). At Northwick Park a previous history of overt infection was significantly associated with apparent bacteriuria (unlike the situation in Aberdeen), but bacteriuria was not confirmed more frequently in those with a previous history of overt infection than in those without.

The incidence of overt infection in Northwick Park mothers without bacteriuria was $0.4 \%$ and in those with apparent bacteriuria $0.9 \%$. If the control group was representative of all our nonbacteriuric pregnant women 19 cases $(0.4 \%)$ of overt infection would have been expected during the study period. For those with confirmed bacteriuria who were offered and accepted treatment the incidence of overt infection was $5 \%$ but among those not offered antibiotics it was $12.5 \%$ (figure). Other studies suggest that $12.5 \%$ is a low incidence of later overt infection in patients with untreated bacteriuria and $30 \%$ or more would have been expected, ${ }^{2}{ }^{212}$ though a rate as low as $4.3 \%$ has been reported. ${ }^{19}$ The low prevalence of bacteriuria and of overt infection may reflect the comparative affluence of our population, half of whom belonged to social classes I and II. If the $12.5 \%$ incidence in the eight untreated patients is representative of the group with confirmed bacteriuria as a whole 10 cases of overt infection would have been expected among the 80 treated patients if no antibiotics had been given, whereas only four cases occurred. The policy at Northwick Park of reserving antibiotics for those with confirmed bacteriuria, which avoided giving antibiotics to $49 \%$ of women with apparent bacteriuria, appears to have been justified.

The difficulties inherent in any programme designed to prevent overt infection by routine testing for and treatment of bacteriuria are shown both by this study and that used for comparison from Aberdeen. Both populations showed the poor predictive ability of the dipslide screening test alone, which was not improved at Northwick Park by adding a previous history of urinary tract infection. Because the number of overt infections was comparatively small at Northwick Park extrapolation to larger numbers must be made with caution. It is evident from the comparison between the two populations that the prevalence in Aberdeen of both apparent bacteriuria and overt infection was not only higher in the untreated bacteriuric women but was also higher in those without bacteriuria at booking who received no treatment. This highlights the difficulties in assessing the effect of treatment by making comparisons between populations.

The cost of the preventive programme described above was roughly $£ 6000$. This might be considered an economic outlay only when the prevalence of bacteriuria is high, as prophylactic 
treatment might prevent a comparatively large number of cases of overt infection. ${ }^{3}$ The advantages are less obvious in a population with a low prevalence such as occurs at Northwick Park. There are, however, effects of bacteriuria on the fetus which must be considered. These include an increase in midtrimester abortion, growth retardation, and preterm delivery. ${ }^{2021}$ The outcome of this study suggests that the decision on whether or not it is worth while to screen pregnant women for bacteriuria depends on the characteristics of the local population, particularly on the prevalence of bacteriuria.

We are grateful to $\mathrm{Mr} \mathrm{H}$ Gordon for allowing us to investigate patients under his care, to Mr D Altman for statistical help and advice, to the nursing staff of the antenatal clinic for collecting specimens, and to Leo Laboratories for the support of MC-B and the provision of antibiotics for the controlled trial within the study.

\section{References}

1 Anonymous. Urinary tract infection during pregnancy [Editorial]. Lancet 1985;ii:190-2.

2 Savage WE, Haij SN, Kass EH. Demographic and prognostic characteristics of bacteriuria in pregnancy. Medicine (Baltimore) 1967;46:385-407.

3 McFadyen IR, Eykin SJ, Gardner NHN, et al. Bacteriuria in pregnancy. Foumal of Obstetrics and Gynaecology of the British Commonwealth 1973;80:385-405.

4 Gilstrap LC, Cunningham FG, Whalley PJ. Acute pyelonephritis in pregnancy: an anterospective study. Obstet Gynecol 1981;57:409-13.
5 Chng PK, Hall MH. Antenatal prediction of urinary tract infection. $\mathrm{Br} \mathcal{J}$ Obstet Gynaecol 1982;89:8-11.

6 Norden CW, Kass EH. Bacteriuria of pregnancy-a critical appraisal. Annu Rev Med 1968;19: 431-70.

7 Campbell-Brown M, McFadyen IR. Bacteriuria in pregnancy treated with a single dose of cephalexin. Brf Obstet Gynaecol 1983;90:1054-9.

8 Turck M, Goffe B, Petersdorf RG. Bacteriuria of pregnancy. Relation to socioeconomic factors. NEngl f Med 1962;266:857-60.

9 Henderson $M$, Entwhistle G, Tayback $M$. Bacteriuria and pregnancy outcome: preliminary findings. Am f Public Health 1962;52:1887-93.

$10 \mathrm{Kass}$ EH. Bacteriuria and the diagnosis of infections of the urinary tract. Arch Intern Med 1957;100:709-14.

11 Mond NC, Percival A, Williams JD, Brumfitt W. Presentation, diagnosis and treatment of urinary-tract infections in general practice. Lancet $1965 ; \mathrm{i}: 514-6$.

12 Kincaid-Smith P, Bullen M. Bacteriuria in pregnancy. Lancet $1965 ;$; $395-9$.

13 Rogosa M, Mitchell JA, Wiseman RF. A selective medium for the isolation and enumeration of oral and fecal lactobacilli. $\mathcal{J}$ Bacteriol 1951;62:132-3.

14 MacFarlane RW. A semi-selective medium for the isolation of Veillonella species from the mouth. J Clin Pathol 1977;30:191-2.

15 Borriello $P$, Hudson M, Hill M. Investigation of the gastrointestinal bacterial flora. In: Russell RI, ed. Clinics in gastroenterology. Vol 7. London: WB Saunders, 1978:329-49.

16 Monto AS, Rantz LA. The development character of bacteriuria in pregnancy. Experience with a non-indigent population. Annu Rev Med 1963;59:186-93.

17 Stamm WE, Wagner KF, Amsel R, et al. Causes of the acute urethral syndrome in women. $N$ Engl f Med 1980;303:409-15.

18 Lenke RR, Van Dorsten JP, Schifrin BS. Pyelonephritis in pregnancy: a prospective randomized trial to prevent recurrent disease evaluating suppressive therapy with nitrofurantoin and close trial to prevent recurrent disease evaluating suppressiv
surveillance. Am $\mathcal{I}$ Obstet Gynecol 1983;146:953-7.

19 Mattingly RF, Borkowf HI. Clinical implication of ureteral reflux in pregnancy. Clin Obstet Gynecol 1978;21:863-73.

20 Baird D. Infection of the urinary tract in the puerperium. Fournal of Obstetrics and Gynaecology of the British Empire 1936;43:435-52.

21 McGrady GA, Daling JR, Peterson DR. Maternal urinary tract infection and adverse fetal outcome. Am $\mathcal{F}$ Epidemiol 1985;121:377-81.

(Accepted 23 April 1987)

\title{
Neurodevelopmental outcome in babies weighing less than $2001 \mathrm{~g}$ at birth
}

\author{
NEIL MARLOW, STEPHEN W D'SOUZA, MALCOLM L CHISWICK
}

\begin{abstract}
From 1976 to 1980,1034 infants with birth weights of $500-2000 \mathrm{~g}$ were cared for in the neonatal medical unit; 724 were discharged. Twenty (2:8\%) subsequently died and $654(90.3 \%)$ were followed up at a median age of 3 years 3 months. Fifty five (7.6\%) survivors had major neurodevelopmental handicaps not attributable to congenital anomalies. Increasing prevalence of major handicap was found with decreasing birth weight and gestation. Children with birth weights of less than $1251 \mathrm{~g}$ had a higher incidence of all major disabilities. Handicapped children with a birth weight less than $1251 \mathrm{~g}$ were more likely to have blindness, deafness, multiple disabilities, and more severe cerebral palsy. There were $146(20 \cdot 2 \%)$ children with minor disabilities: neurological impairments $(n=11)$, borderline results on psychometric testing $(n=$ 18), visual impairments $(n=52)$, hearing impairments $(n=40)$, and speech impairments $(n=71)$. Children weighing less than $1251 \mathrm{~g}$ at birth had a higher incidence of minor visual and hearing impairments. In 389 children the mean Griffiths quotient was 101.6 (SD 17.2) (range 50-147), and 158 children had a mean
\end{abstract}

Neonatal Medical Unit, North Western Regional Perinatal Centre, St Mary's Hospital, Manchester M13 OJH

NEIL MARLOW, DM, MRCP, research fellow

STEPHEN W D'SOUZA, PHD, FRCP, senior lecturer in child health

MALCOLM L CHISWICK, MD, FRCP, consultant paediatrician

Correspondence to: Dr Neil Marlow, Department of Child Health, Liverpool Maternity Hospital, Liverpool L7 7BN.
Wechsler preschool and primary intelligence quotient of 101.8 (13.2) (range 56-127): these quotients did not vary with birth weight or gestation but did vary with socioeconomic group, schooling, and family structure.

During the study period an improving prognosis in terms of both survival and handicap was observed in children weighing less than $1251 \mathrm{~g}$ at birth.

\section{Introduction}

Neurodevelopmental follow up surveys of babies born to mothers who live in a single geographical area provide useful epidemiological information about childhood handicap. In investigations of handicap among very low birthweight infants, however, the geographical base must be large or the study prolonged to generate a sufficient number of surviving children. In addition, unless ill babies in the geographical population have been exposed to similar standards of neonatal care it is difficult to interpret the relation between shifts in mortality and neurodevelopmental outcome. Thus one hospital may contribute excess mortality but low morbidity among survivors and another may contribute low mortality but excess morbidity. Individual neonatal units report an increase in the survival of low birthweight infants associated with the introduction of neonatal intensive care. It is essential for these units to monitor changes in neurodevelopmental outcome among their survivors. ${ }^{1}$

Regional neonatal units can provide detailed information on large numbers of very low birthweight survivors who are exposed to a consistent and defined standard of care. Trends in mortality and neurodevelopmental outcome can thus be observed against the 